\title{
The Effect of Timber Harvesting on Fluctuation of Peat Water Level and Subsidence of Peat-Soil Surface
}

\author{
Sona Suhartana \& Yuniawati
}

Center for Forest Products Research and Development, Jln. Gunung Batu No 5, Bogor 16610, Indonesia Telp.(0251)8633378; Fax. (0251)8633413,E-mail sona.suhartana@gmail.com \& yunia_las@yahoo.co.id

\begin{abstract}
A goal of timber harvesting is to increase timber production through removing the timber from the forest using some harvesting techniques. A peatland is a fragile ecosystem and may degraded easily. Logging activities may adversely affect the soil compactness that disrupt the peat drainage system as well as subsidence, then ultimately may cause the sustainability of peat. This study was focused on examining the effect of timber harvesting activities in peat forest plantation. The peatland damage may in the form of increased bulk density, water level fluctuations of peat (TMA), subsidence, irreversible, and $\mathrm{C}$ emissions. The objective of the study was to find out the effect of timber harvesting in peatland plantations to peat water fluctuations and subsidence. The results showed that logging activities caused: (1) The average of water table and water level were about 1.03 and $0.967 \mathrm{~m}$; and (2) Subsidence about -8 to $-12.5 \mathrm{~cm}$ with the average was $-11.0 \mathrm{~cm}$.
\end{abstract}

Keywords: timber harvesting, productivity, water fluctuations, subsidence.

\section{INTRODUCTION}

Activities of timber harvesting in plantation forests intend to cope with the needs for continually supplying wood raw materials for pulp and paper industries. Not only are those activities performed at mineral areas, but also carried out at peatland areas. Timber harvesting at peatland should proceed with great care and cautious action, as the peat characteristics are fragile and brittle. Peat is irreversible ecosystem, thus once the peat is damaged, it will be difficult to return to its normal situation. The timber harvesting at peatland area that conducted in arbitrary ways may bring about substantial and severe damage to the vegetation and peatland themselves.

For facilitating and enabling the timber harvesting activities in peatland areas, forest companies commonly build a canal for transportation. Besides for transportation, the canals are also beneficial for water management, thereby enabling the vegetation to grow well. The canal development in peatland

Correspondence Author:Sona Suhartana, Center for

Forest Products Research and Development

Jln. Gunung Batu No 5, Bogor 16610, Indonesia.

Email: sona.suhartana@gmail.com

Journal of Wetlands Environmental Management

Vol 6, No 1 (2018) $74-84$

http://dx.doi.org/10.20527/jwem.v6i2.178 areas may cause the lowering of soil-water surface as well as induces faster decomposition at the layers over the soil-water surface. This condition should affect the chemical characteristics of peat. Besides affecting the height of soil-water surface, canal may also bring about the subsidence of peat-soil surface. The research of Goosen (1971) noted that the existence of canal affected the increase in soil bulk-density and rendered the occurrence of subsidence, accompanied by the lowering of soil-water retention at peat soil in Alberta, Canada. He further observed that seven years after the completion of canal development, average of soil bulk density (at 0-40 cm depth) increased 63\%, and soil-water retention decreased from -5 to $-15000 \mathrm{~cm}$, or $66 \%$ greater than that in peat soil area without the presence of canal.

In peat soil, the construction of channels may cause a drop of groundwater, then lead to increase risk of forest fires. Under these conditions, studying the behavior of groundwater in the peat to maintain a certain level of high water table and reduce the risk of forest fires is a very crucial tasks. The best way 
to monitor the behavior of groundwater is by measuring directly the groundwater in the wells. However, the cost and effort required to monitor the groundwater behavior is relatively high and time consuming. There were limited numbers of groundwater parameters of peat swamp areas have been readily measured in the field (Schot et al., 2012).

The surface soil horizons were mainly transformed due to long-term forestry drainage. Increased aeration of these layers had enhanced their content of labile forms of carbon and they were undergoing secondary transformation. Soil transformation was more advanced in fen peatlands than in transitional mire or raised bogs. Only the fens exhibited characteristic evidence of the moors-forming process. Further drying of these soils will negatively affect their rewetting potential and significantly reduce the effective application of restoration treatments. In order to reduce organic matter transformation and loss from the investigated peatland areas, their drainage ditches should be blocked. Additionally, some trees should be removed from their central areas to reduce evapotranspiration (Glina et al., 2016).

In managing of peatlands, it is essential to pay thorough attention to the water-management system. Water management at peatlands is closely related with fluctuation of water-surface height. Water surface height that is too deep can induce peat damages. According to Sukariawan et al., (2015), moisture content of peat soil less than $300 \%$ (reaching approximately 273\%) have been categorized into a critical moisture content condition (moisture content at permanently withering point) that causes the death/withering of plants (vegetation). Such critical condition may trigger peat degradation initiated by the forming of pseudosand, which is characterized by irreversible drying. Peat degradation will further continue to particular occasion with the occurrence of soil-surface subsidence, when peat-soil water be always in critical moisture content condition and with the level of peatwater surface too deep.

Soil-surface subsidence due timber harvesting causes the decrease of peat capability to hold or with stand the water. When the peat dome already undergoes as much shrinkage as one-meter thick, then the peat-soil will lose its capability to hold water up to $90 \mathrm{~cm}$ or being equivalent to $9,000 \mathrm{~m}^{3} \mathrm{ha}^{-1}$. It means that the area with one-hectare size and its surrounding will receive water more than $9,000 \mathrm{~m}^{3}$, if there is a heavy rains. Conversely, due to less amount of water reserve as stored during rainy season, then the water reserve that could be received by the surrounding areas is lesser and such areas is becoming more vulnerable to the drought during dry season (Agus \& Subiksa, 2008). From the foregoing backgrounds, then the objective of this research was to examine the effect of timber harvesting at peat-soil area's plantation forest on the fluctuation of peat-water level and subsidence of peat-soil surface.

\section{MATERIALS AND METHODS}

\section{Date, study site and materials}

Research on preparing plots for measuring fluctuation of water-surface level and plots for subsidence of peat-soil surface took place in 2013, while the related observation was conducted from the year 2013 to 2015 . This research was carried out in the working area of forestry company, Satria Perkasa Agung Co. Ltd located within Pelalawan Regency, Riau Province. Geographically, this study site is located between $102^{\circ} 50^{\prime}$ and $102^{\circ} 10^{\prime}$ east longitude (MEL); as well as between $01^{\circ} 10^{\prime}$ and $01^{\circ} 0$ north latitude (PNL). In general, the configuration of the research area is gentle having class slope of $\mathrm{t} 0-8 \%$, with altitude around 2-10 $\mathrm{m}$ above sea level. The soils are typically Troposaprist, Tropohemist, Dystropepts, Tropudult, and Trofofiblist, while the climate belongs to Type A (Schmidt and 
Ferguson criteria). The highest rainfall ever reached at about $311.8 \mathrm{~mm} \mathrm{month}^{-1}$, while the lowest at about $137.9 \mathrm{~mm}$ month $^{-1}$, with no dry month. Forest stands species are mainly as Acacia crasicarpa trees of the Leguminosae family, with stand density of approximately 1,000 trees $\mathrm{ha}^{-1}$. The trees are mostly characterized with no buttress roots. Meanwhile, the undergrowth vegetation exhibits medium stand-density in average. The materials used in this study consisted of peat soil samples, paint, brushes, and questionnaires and the tools used were distance-measuring devices, rulers, and devices for measuring water-surface height (level) and surface subsidence.

\section{Research procedures}

Primary data were mainly obtained through direct observation and measurement of the surface subsidence and soil-water fluctuation in the field. Meanwhile, secondary data particularly that related to harvesting activities, stand productivity and cost which were collected from many sources. Some data were acquired from the research results conducted previously by the authors at the same location (Suhartana \& Yuniawati, 2016) as well as from direct interview with the related employees.

\section{Fluctuation of soil-water level}

a. The measurement of the soil-water level was done by purposively determine one cutting plot, representing the physical condition of local environment of the study site;

b. At the selected cutting plot, the three sample plots (MP), having size of $100 \mathrm{~m}$ by $100 \mathrm{~m}$ and with spacing distance of about $350 \mathrm{~m}$ between MP were prepared (Figure 1);

c. At each of the MP's one observation point was set up; d. Furthermore, at each observation point, a hole with the diameter size ranging about 15$40 \mathrm{~cm}$ was dug;

e. Measuring the soil-water depth with ruler starting from the peat surface moving downward to soil-water surface;

f. The measurement was conducted periodically at every 6-month periods during two years research period.

\section{Subsidence of peat-soil surface}

The measurement of subsidence was also done as follows

a. Selection of the MP for observation

b. At each of the observation points, the measurement of soil depth using measuringstick was done. The stick is made from lightweight material, durable and easily obtained.

c. The measurement was also conducted sixmonthly for two years.

After two-years the primary data that consisted of cumulative subsidence for each consecutive six-month period and the height changes of soil-water surface for every consecutive six-month period could be calculated. Meanwhile, simultaneously the procurement of secondary data that referred to timber productivity and harvesting cost was also completed. The details are as follows:

1. Calculation of the subsidence level was done by measuring the rate of subsidence at every end of the consecutive six-month periods (calculating the difference between two sixmonthly consecutive measurement time). After two-year duration, all the overall difference was summed up cumulatively, and the regarded as the subsidence of peat-soil surface;

2. Measuring changes of the soil-water surface level was done by initially measuring the 
height of water surface at the cutting plot and on canal at every end of the consecutive sixmonth periods, which lasted for two years. Afterwards, the soil-water fluctuation could be determined by taking average of those overall obtained changes in height of soilwater surface.

3. Timber productivity and harvesting cost were obtained from the previous research results by the authors (Suhartana \& Yuniawati, 2016) at the same location as those for acquiring subsidence and fluctuation data.

\section{Data analysis}

The fluctuation of soil-water surface level and subsidence of peat-soil surface were tabulated and processed by considering the average and standard deviation values. Meanwhile, to look into whether the productivity of timber harvest affected the occurrence of subsidence or not was conducted by One-sample t-Test, with the aid of SPSS 18 statistical software.

The hypothesis examined in this study was as follows:

Ha: The productivity of timber harvesting affected the occurrence of subsidence;

Ho: The productivity of timber harvesting did not affect the occurrence of subsidence.

When the calculated-t value exceed the table-t value, then reject Ho; and conversely should the calculated-t value be lower than the table-t value, then accept Ho.

\section{RESULTS AND DISCUSSION}

\section{Fluctuation of peat-water level}

Measurement results of the height of peatwater surface (HPWS) due to timber harvesting at the HPWS on the cutting plot (water table) and at the one on canal (water level) were presented in Table 1. It is shown that there were fluctuations of HPWS either on the cutting plot or on the canal until the fourth semester of the two-year duration. HPWS on the cutting plot and the canal each exhibited average water fluctuation at $1.030 \mathrm{~m}$ and $0.967 \mathrm{~m}$ consecutively. Those figures suggested that water-surface elevation level on the cutting plot was referred to as low, and there already suffered from great fluctuation of HPWS.

Such low level of water surface indicated that substantial damage had occurred to the peat structure (texture). The greater the fluctuation of HPWS, then the lower the level of soil-water surface, and therefore this situation could threaten the peat sustainability. This finding is in line with Soewandita (2008) about soil-water surface of the peat at area in the naturally reforested reclamation area. In that condition also mentioned that such soil-water surface exhibited high (near surface) about $0.15 \mathrm{~m}$. The high-level soil-water surface could imply that that its threat to environment damage seemed relatively small. Sukariawan et al. (2015) noted that the low level of soil-water surface which deep reaching at about of $88.6 \mathrm{~cm}$ (below surface) could accelerate the faster peat decomposition rate, as indicated by the lower $\mathrm{C} / \mathrm{N}$ ratio as well as decreasing the site quality (fertility) of peat with the decreases in ash, exchangeable-K, available-P, and total-P contents.

If referring to the above, then the fluctuation of HPWS level both in cutting plots as well as in the canal belonged to the low category. Such low level of water surface could indicate an urgent management of the peat-water condition.

When the peat-soil area be provided with adequate drainage system, then the water output at water balance increases, causing the soilwater storage to become less as observed by the lowering of soil-water surface. With such lowering, then the decomposition rate of peat increases. The consequence that comes about is the occurrence of subsidence and the releases (emission) of greenhouse gases through 
The research of Suhartana et al., (2012) revealed that the average of fluctuation of HPWS at the cutting plot (water table) is about $61.75 \mathrm{~cm}$ per four months and at the canal (water level) about $52.25 \mathrm{~cm}$ per four months as well. Changes in HPWS that occurred for four months at the cutting plot on the area prior to timber harvest strongly suggested that the open area due to timber harvesting could enhance the fluctuation of HPWS. The difference in HPWS between at the cutting plot (water table) and at the canal (water level) that reached $9.4 \mathrm{~cm}$ per four months was regarded as high.

In this research, such high value of HPWS fluctuation was suspiciously worried that there had already suffering from over drainage. Over drainage refers to the event or phenomena that occurred at the peat area cauterized by water moving out of soil mass excessively due to the infiltration process that occurred at peat area which ran imperfectly (less/minimal). Such peat soil could be judged as damaged due to its physical changes, brought about by vegetation changes owing to fire disaster and establishment of improper infrastructures. This condition may cause imbalance water-content in at the peat area, as the area sustained an illegal competition in constructing the channels already existed. The depth of drainage which was set up by the Company was $3 \mathrm{~m}$ in average. Over drainage became one of the several factors that caused the decrease in peat surface (subsidence) (Arrizmi et al., 2012).

Susilo et al., (2013) mentioned that the fire risk in the tropical peatland areas could be measured and predicted based on GWL fluctuation model. The model in this study showed that in the years of El Nino, the elevation of groundwater in the area observed decreased dramatically, especially in the dry season. The decline was more than $40 \mathrm{~cm}$ below the soil surface. This means the possibility of a peat fire danger is high for this area. In the future, this kind of models are expected to be used to determine the level of fire hazard possibility of peatland and can serve as a reference in determining the strategy in handling of peatland fires in Indonesia.

The water retained in an undisturbed peatland is equivalent to $90 \%$ of its weight and $300 \%$ of its volume. Therefore, the more a peatland loses water, the more it loses volume. Drainage of water results in the process of subsidence of peat deposits, involving the densification and depletion of organic matter. The rate of subsidence of the surface of peatlands depends on the kind of peat, density of its mass, intensity of drainage and type of use (Gnatowski et al., 2010).

Research results by Andrie et al., (2010) also confirmed that the construction of drainage canals excessively could bring about changes in physical, chemical, and biological properties of the peat, and their impacts occurred at the occasion of dry season, whereby level of soilwater surface would be close to the soil surface. This suggested that during the dry season there would occur the shallowing of canals, while conversely during the rain season flood took place in the canal.

Table 1. Height of water surface (water table) at the cutting plot and at the canal (water level) on the area operated by SPA Company

\begin{tabular}{|c|c|c|c|c|c|c|c|c|c|c|}
\hline \multirow[t]{2}{*}{ No } & \multicolumn{2}{|c|}{$\begin{array}{l}\text { Semes- } \\
\text { ter I }\end{array}$} & \multicolumn{2}{|c|}{$\begin{array}{l}\text { Semes- } \\
\text { ter II }\end{array}$} & \multicolumn{2}{|c|}{$\begin{array}{l}\text { Semes- } \\
\text { ter III }\end{array}$} & \multicolumn{2}{|r|}{$\begin{array}{l}\text { Semes- } \\
\text { ter IV }\end{array}$} & \multicolumn{2}{|c|}{ Mean } \\
\hline & WT & WL & WT & WL & WT & WL & WT & $\mathrm{WL}$ & WT & WL \\
\hline 1 & 1.5 & 0.8 & 1.3 & 0.9 & 1.6 & 0.8 & 1.6 & 0.8 & 1.5 & 0.8 \\
\hline 2 & 0.6 & 1.0 & 0.5 & 1.2 & 0.5 & 1.0 & 0.5 & 1.0 & 0.5 & 1.1 \\
\hline 3 & 0.9 & 1.1 & 1.1 & 1.1 & 1.1 & 0.9 & 1.3 & 1.1 & 1.1 & 1.1 \\
\hline $\mathrm{Me}$ & & & & & & & & & 1.03 & 0,97 \\
\hline
\end{tabular}

Remarks: SPA = abbreviation of Satria Perkasa Agung

\section{Subsidence}

Measurement results on subsidence of peatsurface level due to forest harvesting are 
that for each consecutive semester at three measuring plots (MP), there had occurred such subsidence. At the fourth semester, the second and third MP's sustained the subsidence of peat surface as much as $-12.5 \mathrm{~cm}$. Such figure was greater than the subsidence at the other three semesters, which ranged from -8 until $1.2 \mathrm{~cm}$, with average subsidence of $-11.0 \mathrm{~cm}$. That subsidence occurred with the difference $0.5 \mathrm{~cm}$ for each semester; and such was regarded as high.

This research noted higher subsidence value than that the previous research results of Suhartana \& Yuniawati (2011), whereby the subsidence rate after timber harvesting was greater than before harvesting. This implied that activity of timber harvest at swampy plantation forest could bring about the peat subsidence as much $0.375 \mathrm{~cm}^{\text {year }}{ }^{-1}$ as being equivalent to $1.875 \mathrm{~cm}$ in five years. Such great subsidence value that occurred in this research was caused by the peat thickness $\geq 3 \mathrm{~m}$. Barchia (2006) noted that the subsidence rate was affected by depth of drainage and thickness of peat. The deeper the drainage/canal, then the faster would be the subsidence rate. Also, the more immature the peat texture, then faster could be the subsidence rate. On a particular occasion, peat thickness could immensely affected subsidence rate, whereby the rate at the deeper part of the peat was faster than those at moderately-deep and shallow peats.

Such peat-surface subsidence should deserve through and serious attention, as subsidence in great extent could bring negative impacts with the loss of gambut stock and then changed it to mineral mass. Moreover, those changes did not bring out any advantages to the environment, and in fact could threaten the environment sustainability. Even, the mineral that formed due to peat changes contained dangerous poison.
Average peat subsidence rates during the observation period were $3.1-5.2 \mathrm{~cm}^{y_{e}{ }^{-1}}$ on the degraded peatland, reducing to $1.8-2.6 \mathrm{~cm}$ year $^{-1}$ when peat loss due to field fires was discounted, and $1.0 \mathrm{~cm}^{\text {year }}{ }^{-1}$ reducing to 0.7 $\mathrm{cm}$ year $^{-1}$ in the conservation zone. Due to martial law restrictions on access to the Bacho site, measurements of the peat soil respiration rate under various water

table conditions were made mostly at other sites in Thailand with similar climate. During these measurements the position of the water table ranged from $0.92 \mathrm{~m}$ above the peat surface to more than one m below it (Nagano et al., 2013).

Maswar \& Fahmuddin (2016) mentioned that there were numerous negative effects of subsidence on plant productivity, when connoted to the loss of peat soil. The first impact of the subsistence is the loss of specific characteristics of peat that could hold and store water would render the plants unable to receive sufficient amount of water. Secondly, at the soil that became solidified (plugged) or even compacted, its organic matters already changed to irreversible dryness, thereby unable to hold anions as well as cations which were urgently required by plants as their nutrients and for their physiological activities. This situation caused the nutrient adsorption capability to decrease. Finally, at the peat soil that became solidified, plant or vegetation growth even with simple rooting system would be difficult to develop (grow).

The value of subsidence of Histosol, measured by geodetic means, is ranging from 9 to $33 \mathrm{~cm}$, while that of Gleysol from 0 to $4 \mathrm{~cm}$. The mean value of subsidence of the peatland in Sosnowica amounted to $24 \mathrm{~cm}$ over 38 years, which gives a degree of subsidence of $0.6 \mathrm{~cm}$ year $^{-1}$, i.e. a loss of peat mass amounting to $11.5 \%$ of the total resources. The situation is still worse in the case of the peatland in Uhnin, where mineralization and a fire of the peatland 
The one-sample t-test as adopted to assess whether the productivity of timber harvest affected the peat-surface subsidence revealed that the calculated-t value (2.875) exceeded table-t value (2.571, at $\mathrm{df}=5$, and $\alpha=5 \%$ ) (Table 3). Consequently, the alternative hypothesis (Ha) was accepted, while the null the occurrence of such subsidence. In this way, this indicated that not only did the forest enterprises attempt to run after the targeted production, but they also should pay thorough attention to the peat sustainability; and accordingly, the continuity of timber production at the peat area's plantation forest would be secured and kept in effect.

hypothesis (Ho) rejected. This implied that

Table 2. Subsidence of peat-soil surface the SPA Company, Riau

\begin{tabular}{llllll}
\hline $\begin{array}{l}\text { Number } \\
\text { of plot }\end{array}$ & $\begin{array}{l}\text { Semester } \\
\text { I }\end{array}$ & $\begin{array}{l}\text { Semester } \\
\text { II }\end{array}$ & $\begin{array}{l}\text { Semester } \\
\text { III }\end{array}$ & $\begin{array}{l}\text { Semester } \\
\text { IV }\end{array}$ & Mean \\
\hline 1 & -8 & -9 & -10 & -11 & -9.50 \\
2 & -11 & -11.5 & -12 & -12.5 & -11.75 \\
3 & -11 & -11.5 & -12 & -12.5 & -11.75 \\
& & & & Mean & -11.00
\end{tabular}

Remarks: SPA = abbreviation of Satria Perkasa Agung

Table 3. T-test regarding the effect of logging productivity on subsidence

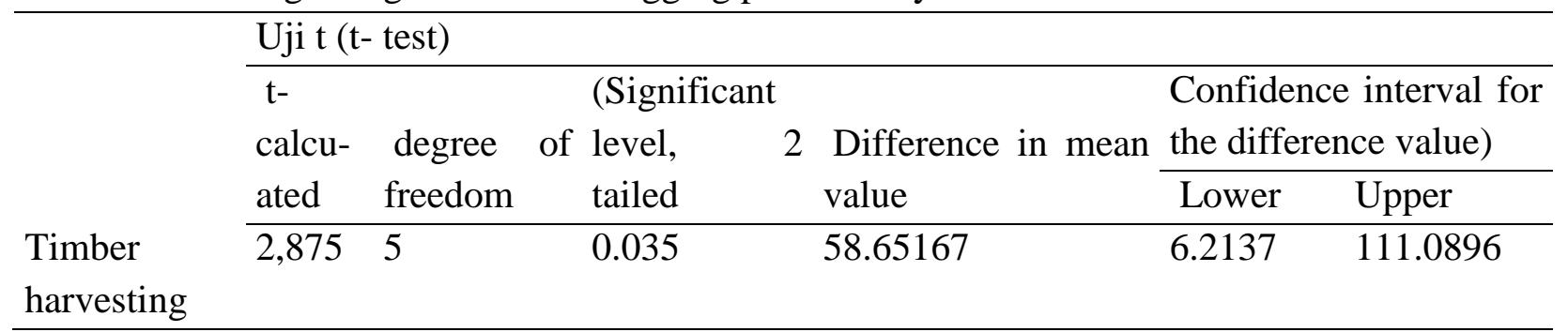

\section{Productivity and timber harvesting cost}

Measurement results on average productivity and cost of timber harvest are presented in Table 4. The table revealed that such average productivity and cost that resulted from the research as conducted at the same location were higher than those yielded by two research results (designated as $\mathrm{A}$ and $\mathrm{B}$ ) as presented in Table 5, especially about transportation/hauling activities. This could happen, because the hauling activities at the SPA Company's forest enterprise employed two transportation means (tools), which consisted of small iron boats for wetland areas, and trucks at

Journal of Wetlands Environmental Management dryland areas. Those double transportation systems could therefore increase the volume of timber that would be transported. It could be mentioned that part of the condition at cutting plots of the study area had wetland areas which were flooded by water; while another part comprised dryland areas on which the trucks could pass.

Table 4 also disclosed that average production cost of timber harvest particularly in the skidding activities at the same research location was higher than those resulted from A's research as depicted in Table 5. Such higher production cost in this research was brought about by the condition at research area, whereby 
the thickness of peat mass there exceeded 3 meters, thereby causing difficulty for the excavator to perform the maneuver or other sorts of movement.

Peat mass which was thick could render the track platform for the excavator unstable (could not stand still or always moving). Consequently, the operators had to be very careful in running the excavators or other heavy-weight tools. Such carefulness brought out an effect on increasing the working duration, thereby increasing as well the average cost of hauling production.

Several research results that revealed productivity and cost of timber harvest at peatsoil area are presented in Table 5.

Table 4. The average of logging cost and productivity at PT SPA Riau.

\begin{tabular}{lllll}
\hline No & Aspects & Kind of logging tools & $\begin{array}{l}\text { Productivity } \\
\left(\mathrm{m}^{3} \mathrm{~h}^{-1}\right)\end{array}$ & $\begin{array}{l}\text { Logging } \\
\text { cost } \\
\left(\mathrm{Rp} \mathrm{m}^{-3}\right)\end{array}$ \\
\hline 1 & Felling & Chainsaw Stihl MS-381 & 8.000 & 11.665 .098 \\
2 & Skidding & Excavator Hitachi ZX 110 & 5.899 & 70.566 .909 \\
3 & Loading & Excavator Kobelco SK 200-8 & 87.292 & 6.694 .313 \\
4 & Hauling & Swamp Barge & 116.379 & 5.387 .463 \\
& & Logging truck Mitsubishi 6D16D & 111.602 & 5.617 .987 \\
5 & Unloading & Excavator Komatsu PC 300 L C-8 & 88.735 & 6.585 .451 \\
\hline
\end{tabular}

Source: (Suhartana \& Yuniawati, 2016)

Table 5. The average of logging cost and productivity in a peatland brought out by other research activities

\begin{tabular}{|c|c|c|c|}
\hline $\begin{array}{l}\text { Other re- } \\
\text { searches }\end{array}$ & Aspects & $\begin{array}{l}\text { Productivity } \\
\left(\mathrm{m}^{3} / \mathrm{hrs}\right)\end{array}$ & $\begin{array}{ll}\text { Logging } & \text { cost } \\
\left(\mathrm{Rp} / \mathrm{m}^{3}\right) & \end{array}$ \\
\hline \multirow[t]{5}{*}{ A } & Felling & 7,863 & $7,306.9$ \\
\hline & Skidding & 21,100 & $23,633.5$ \\
\hline & Loading & 88,201 & $5,649.3$ \\
\hline & Unloading & 97,641 & $5,102.5$ \\
\hline & Hauling & 78,461 & $5,614.6$ \\
\hline \multirow[t]{2}{*}{ B } & Felling (Riau) & 10,022 & 5,618 \\
\hline & Felling (Jambi) & 6,201 & $9,261.50$ \\
\hline
\end{tabular}

Remarks: $\mathrm{A}=($ Suhartana \& Yuniawati, 2011) $\mathrm{B}=($ Suhartana \& Yuniawati, 2010 $)$

\section{CONCLUSION}

The thickness of the peat mass is significantly affect the productivity of timber harvesting, the thicker the peat then the lower productivity. Timber harvesting contribute a significant factor on the fluctuation of waterlevel. The height of water-surface level (HWSL) either in cutting plot or in canal, i.e. consecutively 1.03 and $0.967 \mathrm{~m}$. The greater 
the fluctuation value of HWSL, then the lower would be the peat-water surface level; and the more threatened would be the peat sustainability. The subsidence of peat surface level due to timber harvest ranged about -8 until $-12.5 \mathrm{~cm}$ for the overall semester (of the total two year duration), with average subsidence at -11.0 m. Such subsidence occurred with difference reaching $0.5 \mathrm{~cm}$ for each semester

\section{ACKNOWLEDGEMENT}

The authors would like to express sincerely appreciation to Prof. Dr. Ir. I Nengah Surati Jaya, M. Agr, who giving many correction and suggestion for improvement of the initial draft.

\section{REFERENCES}

Agus F, Subiksa IGM. 2008. Lahan gambut: potensi untuk pertanian dan aspek lingkungan, Balai Penelitian Tanah, Badan Penelitian dan Pengembangan Pertanian. P. 36. Balai penelitian Tanah dan World Agroforestry Centre (ICRAF), Bogor.

Andrie E, Fengky FA, Usup AD, Satata B, Wahyudi T. 2010. Dinamika kedalaman muka air tanah dan karakteristik tanah gambut dekat saluran drainase eks proyek lahan gambut sejuta hektar di Kalimantan Tengah. In Seminar Ilmiah VI Lingkungan Tropis. Palangkaraya. Retrieved from file:///D:/Backup Data C/Pustaka subsidensi Mendeley/Andrie.html

(Accessed 12 Mei 2012).

Arrizmi F, Kartini, Yuniarti E. 2012. Pengaruh infiltrasi terhadap penurunan permukaan tanah pada lahan gambut kawasan konservasi taman wisata alam (TWA) Baning Kabupaten Sintang.http://www.Portalgaruda.org/article
.php?...Pengaruh\%20Infiltrasi.Html.

Accessed 4 Agustus 2013).

Barchia MF. 2006. Gambut agroekosistem dan transformasi karbon (Cetakan 1). P 196. Gadjah Mada University Press. Yogyakarta.

Glina B, Bogacz M, Gulyas B, Zawieja P, Gajewski, Kaczmarek Z. 2016. The effect of long-term forestry drainage on the current state of peatland soils: A case study from the Central Sudetes, SW Poland, Mires and Peat, 18 (21): 1-11, DOI: 10.19189/MaP.2016.OMB.239

Gnatowski T, Szatyłowicz J, Brandyk T, Kechavarzi C. 2010. Hydraulic properties of fen peat soils in Poland, Geoderma, (154):188-195

Goosen D. 1971. Physiography and soils of the Llanos Orientales, Colombia. book. Enschede:

ITC-Enschede-TheNetherlands. http://doi.org/10.1016/00167061(73)90053-0 (Accessed 12 Mei 2012).

Grzywna A. 2017. The degree of peatland subsidence resulting from drainage of land, Environ Earth Sci, (76) : 76-559. DOI 10.1007/s12665-017-6869-1.

Maswar, Fahmuddin A. 2016. Cadangan karbon dan laju subsiden pada beberapa jenis penggunaan lahan dan lokasi lahan gambut tropika Indonesia. In: Prosiding seminar nasional pengelolaan berkelanjutan lahan gambut terdegradasi untuk mitigasi GRK dan peningkatan nilai ekonomi, Badan Penelitian dan Pengembangan Pertanian, Jakarta, 18-19 Agustus 2014, p. 25-44.

Nagano $T$, Osawa $K$, Ishida $T$, Sakaiz $K$, 
Vijarnsorn P, Jongskul

A. 2013.

Subsidence and soil $\mathrm{CO}_{2}$ efflux in tropical peatland in Southern Thailand under various water table and management conditions. Mires and Peat, 11(6): 1-20.

Satriadi D, Kurnianto S. 2016. Topik C2 Hidrologi lahan gambut Indonesia 1. Retrieved from http://www.cifor.org/ipntoolbox/wp-content/uploads/pdf/C2.pdf (Accessed 4 Agustus 2013)

Schot PP, Pieber SM. 2012. Spatial and temporal variations in shallow wetland groundwater quality. Journal of Hydrology, (422): 43-52.

Soewandita H. 2008. Studi muka air tanah gambut dan implikasinya terhadap degradasi lahan pada beberapa kubah gambut di Kabupaten Siak. JAI, 4(2): 103108.

Suhartana S, Yuniawati. 2010. The Effect of Logging on Peat Land Conditions: A case study at a peat swamp forest company in Riau. In: The First International Symposium of Indonesian Wood Research Society. Dwianto, W \& A. Kusumaningtyas (Eds.), Bogor 2009, p. 300-306.

Suhartana S, Yuniawati. 2011. Peningkatan produktivitas pemanenan kayu melalui teknik pemanenan kayu ramah lingkungan: Kasus di satu perusahaan hutan rawa gambut di Kalimantan Barat. Jurnal Penelitian Hasil Hutan, 29(4): 369-384.

Suhartana S, Yuniawati. 2016. Teknik pemanenan kayu yang tepat di hutan tanaman rawa gambut guna meningkatkan produktivitas. Draft Jurnal.
Suhartana S, Yuniawati, Roliadi H. 2012. The Effect of Logging at Peat Swamp Forest on Subsidence, $\mathrm{CO}_{2}$ and $\mathrm{CH}_{4}$ Emissions, and Peat-water Fluctuation: Case study at a peat-swamp forest area in West Kalimantan. In: Proceedings of 3rd International Workshop on Wild Fire and Carbon Management in Peat-Forest in Indonesia. M. Osaki, H. Takahashi, T. Honma, T. Hirano, H. Hayasaka, T. Kohyama, E. Momota (Eds.), Center for Sustainability Science Hokkaido University, Sapporo and University of Palangka Raya, tahun 2012. p. 231-238.

Sukariawan A, Rauf A, Setiawan A, Santoso B. 2015. Pengaruh kedalaman muka air tanah terhadap lilit batang karet Clon $\mathrm{Pb} 260$ dan sifat kimia tanah gambut di Kebun Meranti RAPP Riau, Jurnal Pertanian Tropik, 2(1): $1-5$.

Susilo GE, Yamamoto K, Imai T. 2013. Modeling groundwater level fluctuation in the tropical peatland areas under the effect of El Nino. Procedia Environmental Sciences, (17): 119-128. DOI: 10.1016/j.proenv.2013.02.019. 